\title{
Quality of life after mastectomy and its relation with muscle strength of upper limb
}

\author{
Qualidade de vida pós-mastectomia e sua relação com a força muscular de membro superior
}

Calidad de vida postmastectomía y su relación con la fuerza muscular de los miembros superiores

Suelen Helena da Silva', Lydia Christmann Espindola Koetz', Eduardo Sehnem', Magali Teresinha Quevedo Grave ${ }^{1}$

\begin{abstract}
I This research transversal, analytical, exploratory and quantitative approach aimed to identify the quality of life of women who have had a mastectomy surgery, relate the results with the strength of the upper limb muscle affected and draw a sociofunctional profile. A total of 10 women participated, from 30 to 60 years old, who underwent to unilateral modified radical mastectomy in a medium-sized hospital in an inner city of Rio Grande do Sul, for at least one year from the date of data collection. The strength of the upper limb muscle was evaluated by manual testing and the handgrip was tested with the dynamometer. A sociofunctional questionnaire was applied and the quality of life data were collected through the European Organisation for Research and Treatment of Cancer (EORTC) QLQ-C3O questionnaire, followed by the module BR-23. The strength had decreased in all muscle groups homolateral to the surgery. The life quality in a global health bases resulted as regular. The main changes found in the functionality were at scales: emotional, cognitive and sexual. Statistically, it was found significance and correlation between physical health and social function ( $p=0.04 ; r=0.65$ ), cognition and functional performance $(p=0.01 ; r=0.75)$, emotional performance and cognition ( $p=0.005 ; r=0.9$ ) and between handgrip of the affected limb with the global health ( $p=0.008 ; r=0.77$ ). Breast cancer and mastectomy has a direct impact on the upper limb muscle strength, functionality and on life quality of women, in sexual, cognitive and emotional domains, and physiotherapy plays an important role in the rehabilitation and in social rehabilitation of these.

Keywords I Mastectomy; Women; Breast neoplasms; Muscle strength; Quality of life; Physical therapy specialty.
\end{abstract}

RESUMO I Este estudo transversal, analítico, exploratório e quantitativo teve como objetivo identificar a qualidade de vida (QV) de mulheres mastectomizadas, relacionar os resultados à força muscular do membro superior afetado (MSA) e traçar um perfil sociofuncional. Participaram 10 mulheres, com idade de 30 a 60 anos, que realizaram mastectomia radical modificada unilateral em hospital de médio porte do interior do Rio Grande do Sul havia, no mínimo, um ano contado da data de início da coleta de dados. A força muscular dos membros superiores (MMSS) foi avaliada por meio de testes manuais e a preensão palmar com dinamômetro. Aplicou-se questionário sociofuncional e os dados relativos à QV foram coletados por meio do questionário European Organisation for Research and Treatment of Cancer (EORTC) QLQ-C30, módulo BR-23. A força estava diminuída em todos os grupos musculares homolaterais à cirurgia. A QV na saúde global foi percebida como regular. As principais alterações encontradas na funcionalidade foram nas escalas emocional, cognitiva e sexual. Estatisticamente, foi encontrada significância e correlação entre a saúde física e função social ( $p=0,04$; $r=0,65)$, cognição e desempenho funcional ( $p=0,01$; $r=0,75)$, desempenho emocional e cognição ( $p=0,005$; $r=0,9$ ) e entre força de preensão palmar do membro afetado com a saúde global ( $p=0,008 ; r=0,77$ ). O câncer de mama e a mastectomia exercem impacto direto na força de MMSS, na funcionalidade e na QV de mulheres nos domínios sexual, cognitivo e emocional, e a fisioterapia tem importante papel na reabilitação e reinserção social destas mulheres.

Descritores I Mastectomia; Mulheres; Neoplasias da mama; Força muscular; Qualidade de vida; Fisioterapia.

Study conducted at Centro Universitário UNIVATES - Lajeado (RS), Brazil.

Physical Therapy Course at the Centro Universitário UNIVATES - Lajeado (RS), Brazil. 
RESUMEN I Este estudio transversal, analítico, exploratorio y cuantitativo tuvo como objetivo identificar la calidad de vida (CV) de mujeres mastectomizadas, relacionar los resultados a la fuerza muscular del miembro superior afectado (MSA) y diseñar un perfil sociofuncional. Participaron 10 mujeres, con edad de 30 a 60 años, que realizaron mastectomía radical modificada unilateral en hospital de porte mediano del interior de Rio Grande do Sul hacía por lo menos un año desde la fecha de inicio de la recogida de datos. La fuerza muscular de los miembros superiores (MMSS) fue evaluada por medio de exámenes manuales y la prensión palmar con dinamómetro. Se aplicó cuestionario sociofuncional y los datos referentes a la CV fueron recogidos por medio del questionário European Organisation for Research and Treatment of Cancer (EORTC) QLQ-C3O, módulo BR-23. La fuerza estuvo reducida en todos los grupos musculares homolaterales a la cirugía. La CV en la salud global fue percibida como regular. Los principales cambios encontrados en la funcionalidad fueron en las escalas emocional, cognitiva y sexual. Estadísticamente, fue encontrada significancia y correlación entre la salud física y función social ( $p=0,04$; r=0,65), cognición y desempeño funcional ( $p=0,01 ; r=0,75)$, desempeño emocional y cognición ( $p=0,005 ; r=0,9$ ) y entre fuerza de prensión palmar del miembro afectado con la salud global $(p=0,008$; r=0,77). El cáncer de mama y la mastectomía ejercen un impacto directo sobre la fuerza de MMSS, en la funcionalidad y en la CV de mujeres en los ámbitos sexual, cognitivo y emocional, y la fisioterapia tiene importante papel en la rehabilitación y reinserción social de estas mujeres.

Palabras clave I Mastectomía; Mujeres; Neoplasias de la Mama; Fuerza muscular; Calidad de Vida; Fisioterapia.

\section{INTRODUCTION}

Out of the estimated 576,000 new cases of cancer to appear in Brazil in 2014, 57,000 are cases of breast cancer. It is the most frequent type of cancer in the Southern, Southeast, Midwest, and Northeast regions. In the north, it is the second most incident type ${ }^{1}$.

An important factor that influences breast cancer prognoses is early diagnosis. When detected in its initial stage, a tumor has high chances of being cured ${ }^{2}$. Age is the main risk factor, as the number of cases rapidly increases past the age of 50, and its occurrence is linked to society's urbanization process ${ }^{1}$.

The treatment options include nodule excision with radiation, or mastectomy ${ }^{3}$. These procedures are aggressive, because the physical and emotional consequences are unfavorable to women. The aftereffects include muscle lesions, hemorrhage, scarring complications, sensitivity alterations, fibroses, postural changes, pain, reduction or total loss of amplitude of movement (AM) and muscle strength, compromised respiratory capacity, loss or reduction of functional capacity, and lymphedema in the homolateral $\mathrm{arm}^{4}$. Physical therapy is an important part of post-mastectomy rehabilitation. In order for it to be efficient, the professionals need to be aware of the impact of the changes caused by a mastectomy.

Quality of life (QL) can be defined as an individual's perception of his/her position in life in light of the culture and systems of value in which he/she is inserted and that relate to his/her objectives, expectations, standards, and preoccupations ${ }^{5}$.
Changes in the profile of morbi-mortality, a tendency also in developing countries, point to an increase in the prevalence of chronic degenerative diseases. Advancements in treatments and effective possibilities of control of these infirmities have resulted in higher chances of survival and/or longer lifespans for people who suffer from these illnesses. In this sense, professionals in the field of oncology have observed the necessity of knowing and assessing the life condition of patients in its entirety, with the purpose of increasing their survival rate and improving their $\mathrm{QL}^{5}$.

Information on QL has been considered as indicators in assessments of the efficacy, efficiency and impact of certain treatments targeted at groups of patients with several diseases. Another interest which is directly connected to daily health care practices concerns QL as an indicator in the clinical judgment of specific diseases. The assessment of the physical and psychosocial impact that illnesses, dysfunctions or disabilities can inflict in the people who suffer from them allows for a better knowledge about the patients and their adaptation to a given condition. In these cases, the knowledge about the patient's QL is included in the routine of care, influencing the decisions and therapeutic conducts of health teams ${ }^{5}$.

Knowing the impact that surgical treatments have on muscle and hand grip strength in the upper limb (UL) and on the decreased functioning of the affected upper limb (AUL) enables the definition of strategies used by physical therapists over the course of rehabilitation. In this sense, identifying the impact of the 
decrease of muscle strength on the patients' QL serves as the basis for strategies to promote the social reinsertion of these women.

In this study, our purpose was to identify the QL of women after they had undergone mastectomy, relating muscle strength and the hand grip of the AUL; to outline their sociofunctional profile; and to verify, in accordance with the QLQ-C30 questionnaire, devised by the European Organisation for Research and Treatment of Cancer (EORTC), the domains that most affect QL.

\section{METHODOLOGY}

This is a cross-sectional, analytical, exploratory and quantitative study. To meet the inclusion criteria, the women needed to be between 30 and 60 years old, have undergone unilateral modified radical mastectomy in a medium-sized hospital located in the inner part of Rio Grande do Sul from March 2011 to March 2012, and reside in the municipalities of Lajeado, Estrela, Arroio do Meio, Teutônia, and Colinas. The exclusion criteria were the presence of any pathology in the UL and/or hands at any point in life; being under chemotherapy/ radiotherapy treatment; and presenting cognitive alterations when answering the questionnaire and following the researcher's commands. The selection of the participants is displayed on Figure 1.

The quantitative sample was based on the number of women who had undergone a unilateral modified radical mastectomy between March 2011 and March 2012 at the reference hospital. In this period, the total number of women who lived in cities near the hospital in question was 24 . We calculated a sample of 10 women, a quantity defined based on the total population and respecting an error of $5 \%$.

During data collection, an Informed Consent form was given to all participants. One copy remained with

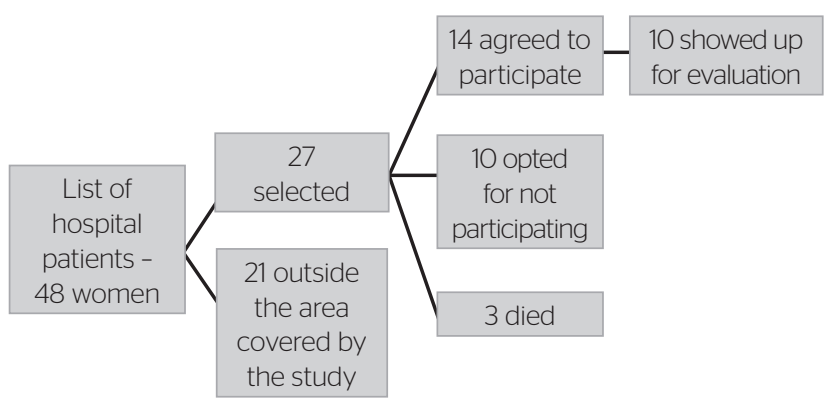

Figure 1. Flowchart of the selection of the study's participants the participant and a second copy with the researcher. We applied a sociofunctional questionnaire with the purpose of outlining the participants' profile. It contained questions about their age, profession, schooling, marital status, number of children, treatments received, current physical therapy treatments, and family history of cancer.

The data pertaining to $\mathrm{QL}$ were collected by means of the EORTC QLQ-C30 questionnaire. It is composed of a generic module for oncologic patients, followed by a BR-23 module, specific for patients with breast cancer. The score for each question varies from 1 to 4, where 1 is for "no", 2 "a little", 3 "moderately", and 4 "a lot" 6

The QLQ-30 quantifies QL according to domains of overall health, functionality, and symptomatology, with a total score that varies from 0 to 100 . A high score on overall health and on the functional scale represents high QL and functionality, respectively; and a high score on the scale of symptoms represents a high level of symptomatology $y^{6}$.

The items on the specific breast cancer module address body image, sexual functioning and pleasure, side effects, symptoms in breasts and arms, and impact of hair loss 6 .

The assessment of hand grip muscle strength was conducted bilaterally with a dynamometer, graded in kilogram-force (kgf) and manufactured by Kratos Equipamentos. The participant was asked to squeeze the device's handle three times with each hand, and the highest value was registered.

The assessment of UL muscle strength was conducted bilaterally, in accordance with O'Sullivan's scale, which varies from 0 to 5 , where 0 indicates absence of muscle contraction, and 5 that the muscle can endure a strong degree of resistance imposed by the physical therapist ${ }^{7}$. We assessed flexor, extensor, abductor, adductor, internal and external rotator shoulder muscles; flexor and extensor elbow muscles; pronator and supinator forearm muscles; and flexor and extensor wrist muscles.

We used the software BIOESTAT 5.0 in the statistical analysis. The quantitative variables were described through averages and standard deviations. The results are presented on tables. We utilized Student's $t$-test and Pearson's correlation to compare the groups. A correlation was considered moderate when it ranged from 0.5 to 0.95 , strong when higher than 0.95 , and perfect when the value obtained was 1 . The values could be either positive or negative. We adopted a significance level of 5\%, and considered as significant values those that yielded $\mathrm{p} \leq 0.05$. The statistical power considered was 0.05 . 


\section{RESULTS}

The participants' sociofunctional profile is displayed on Table 1 . The average scores and standard deviations per domain of the QLQ-C30 questionnaire of all participants can be viewed on Table 2. Concerning their perception of overall health, in the general module the average score was $67.5( \pm 19.8)$, which indicates a perception of QL as reasonable. The average score of overall functionality was $65.3( \pm 19.3)$, classified as regular. The average score regarding symptomatology was 24.9 $( \pm 19.2)$, which pointed to a low level of symptoms. Among the functional scales, the highest scores found referred to social functionality, with an average score of $85( \pm 18.3)$. The lowest score found pertains to their emotional functioning, with an average of $50( \pm 36.7)$.

In the statistical analysis of the functional domains, we found moderate significance and correlation between physical health and social functioning $(p=0.04$; $r=0.65$ ), which shows that the better the participants' physical health, the better their social functioning. We also found a moderate correlation between cognition and functional performance $(\mathrm{p}=0.01 ; \mathrm{r}=0.75)$, that is, the better the participants' cognition, the better their functional performance. In regards to the relation between cognitive functioning and emotional performance, we observed an extreme significance $(p=0.005 ; r=0.9)$, with a strong correlation between these domains, which lead us to conclude that the more heightened their cognitive functioning, the better the emotional functioning.

In the specific module (BR-23) about body image, the participants reflected about the difficulty they feel when observing themselves naked and their satisfaction with their body. In relation to sexual functioning, the average score concerning body image shows moderate QL concerning the patients' perception of their bodies. Regarding sexual functioning, the average score showed low frequencies of sexual relations.

The question about sexual pleasure was answered by the participants who considered themselves sexually active in the previous four weeks. The results are displayed on Table 3. Concerning the domain "side effects of systemic therapy", the average score was 28.1 $( \pm 19.9)$, which reveals a low incidence. The average score of symptoms on the breasts was $46.7( \pm 33.6)$ and on both UL it was also $46.7( \pm 26.6)$; symptomatology was therefore moderate. Only two women reported hair loss in the previous 7 days, with an average impact score of $83(3 \pm 23.6)$, which indicated that they were very uncomfortable with this situation.
In regards to the hand grip strength of the AUL (Table 4) and the domain of overall health, we verified a strong significance $(p=0.008)$ between these factors, as well as moderate Pearson's correlation $(\mathrm{r}=0.773)$.

Table 1. Sample's sociofunctional profile

\begin{tabular}{|c|c|c|c|c|}
\hline Age & $\begin{array}{l}\text { Marital } \\
\text { status }\end{array}$ & Schooling & Pregnancy & $\begin{array}{r}\text { History of } \\
\text { Breastfeeding breast CA in } \\
\text { the family }\end{array}$ \\
\hline M: 45 & $\begin{array}{l}\text { Married: } \\
\quad 6\end{array}$ & $\begin{array}{l}\text { Did not finish } \\
\text { elementary } \\
\text { school: } 5\end{array}$ & Yes: 9 & Yes: 7 \\
\hline \multirow[t]{4}{*}{ SD: 5,4} & $\begin{array}{c}\text { Divorced: } \\
4\end{array}$ & $\begin{array}{l}\text { Finished } \\
\text { elementary } \\
\text { school: } 1\end{array}$ & No: 1 & No: 9 \\
\hline & & $\begin{array}{l}\text { Did not finish } \\
\text { high school: } 2\end{array}$ & & \\
\hline & & $\begin{array}{l}\text { Incomplete } \\
\text { post-secondary } \\
\text { education: } 1\end{array}$ & & \\
\hline & & $\begin{array}{l}\text { Finished post- } \\
\text { secondary } \\
\text { education: } 1\end{array}$ & & \\
\hline
\end{tabular}

M: mean; SD: standard deviation; CA: cancer

Table 2. Scores of quality of life on the domains of the QLQ-C3O questionnaire

$\begin{array}{lccc}\text { Participants } & \text { Overall health } & \text { Functionality } & \text { Symptomatology } \\ 1 & 75.0 & 86.7 & 5.1 \\ 2 & 66.7 & 71.1 & 17.9 \\ 3 & 83.3 & 82.2 & 17.9 \\ 4 & 33.3 & 37.8 & 61.5 \\ 5 & 83.3 & 66.7 & 5.1 \\ 6 & 66.7 & 46.7 & 38.5 \\ 7 & 58.3 & 35.6 & 43.6 \\ 8 & 41.7 & 62.2 & 35.9 \\ 9 & 66.7 & 80.0 & 17.9 \\ 10 & 100.0 & 84.4 & 5.1 \\ \text { Mean } & 67.5 & 65.3 & 24.9 \\ \text { SD } & 19.8 & 19.3 & 19.2\end{array}$

SD: standard deviation

Table 3. Scores of quality of life on the BR-23 questionnaire, specific for breast cancer

\begin{tabular}{|c|c|c|c|c|c|c|}
\hline Participants & $\begin{array}{l}\text { Body } \\
\text { image }\end{array}$ & $\begin{array}{c}\text { Sexual } \\
\text { Functioning }\end{array}$ & $\begin{array}{l}\text { Sexual } \\
\text { Pleasure }\end{array}$ & $\begin{array}{l}\text { Side } \\
\text { Effects }\end{array}$ & $\begin{array}{l}\text { Symptoms } \\
\text { - Breasts }\end{array}$ & $\begin{array}{l}\text { Symptoms } \\
\text { - Arms }\end{array}$ \\
\hline 1 & 0.0 & 0.0 & - & 9.5 & 8.3 & 33.3 \\
\hline 2 & 66.7 & 33.3 & 33.3 & 33.3 & 16.7 & 11.1 \\
\hline 3 & 33.3 & 33.3 & 66.7 & 14.3 & 25.0 & 22.2 \\
\hline 4 & 100.0 & 33.3 & 33.3 & 71.4 & 83.3 & 100.0 \\
\hline 5 & 16.7 & 0.0 & - & 4.8 & 16.7 & 22.2 \\
\hline 6 & 58.3 & 50.0 & 66.7 & 38.1 & 75.0 & 66.7 \\
\hline 7 & 75.0 & 33.3 & 33.3 & 38.1 & 58.3 & 44.4 \\
\hline 8 & 16.7 & 33.3 & 33.3 & 19.0 & 100.0 & 55.6 \\
\hline 9 & 50.0 & 66.7 & 66.7 & 38.1 & 66.7 & 66.7 \\
\hline 10 & 8.3 & 33.3 & 66.7 & 14.3 & 16.7 & 44.4 \\
\hline Mean & 42.5 & 31.7 & 50.0 & 28.1 & 46.7 & 46.7 \\
\hline SD & 32.7 & 20.0 & 17.8 & 19.9 & 33.6 & 26.6 \\
\hline
\end{tabular}

SD: standard deviation 
The stronger the women's hand grip, the better their perception of their overall health.

Upon evaluating the muscle strength of both UL, comparing the healthy and the affected limb, we found a moderate correlation between the flexor muscles $(\mathrm{r}=0.73 ; \mathrm{p}=0.02 ;$ power $=0.7477)$, adductor $(\mathrm{r}=0.78$; $\mathrm{p}=0.01$, power $=0.8274)$ and abductor $(\mathrm{r}=0.8 ; \mathrm{p}=0.0093$; power $=0.8550$ ) muscles of the shoulder and wrist extensors $(r=0.7 ; p=0.05$; power $=0.6303)$. There was a strong correlation between the extensor muscle groups $(r=0.9$; $\mathrm{p}=0.0003$; power $=0.9916)$ and external rotators $(\mathrm{r}=1$; $\mathrm{p}<0.0001)$ of the shoulder. This shows that the more similar the results of the muscle strength evaluation in both body segments, the stronger the correlation found.

\section{DISCUSSION}

According to the domains analyzed in this study by means of the EORTC QLQ-30, the highest values of $\mathrm{QL}$ among the women interviewed were found in the social sphere $(85 \pm 18.3)$. On the other hand, the average of $\mathrm{QL}$ in the emotional sphere was $50( \pm 36.7)$, the lowest found. In another study, upon investigating postmastectomy QL, researchers found alterations in the social functioning of $40 \%$ of the participants, who reported depression, isolation, and decreased sexual pleasure ${ }^{8}$. This finding corroborates the results of the present study in the sense that the less these women shared their routine with their partners, due to fear or shame, the lowest their QL was in the domains presented, especially in regards to their physical and emotional health.

Upon assessing the QL of women treated surgically for breast cancer using the FACT-B questionnaire, researchers found similar results to those of the present study, in which the average values showed a tendency to a good QL and the emotional domain was the most compromised. For the women who had undergone nonconservative surgery, the results presented the worst levels of QL 9 .

In a study on the QL of women undergoing chemotherapy, those without a partner had a more negative perception (63.5) than the women who had a partner (75.9). This pattern was repeated in respect to sexual functioning, as the women who had a partner presented an average of 40.91, and those without a partner, 16.67. On the other hand, the women with partners reported less sexual pleasure (48.14) than the women without partners, who had an average of 67.00. It was also observed that the
Table 4. Hand grip muscle strength (kilogram-force)

$\begin{array}{lcc}\text { Participants } & \text { Healthy } & \text { Affected } \\ 1 & 20 & 18 \\ 2 & 28 & 18 \\ 3 & 20 & 23 \\ 4 & 27 & 11 \\ 5 & 28 & 26 \\ 6 & 27 & 09 \\ 7 & 31 & 24 \\ 8 & 23 & 10 \\ 9 & 27 & 13 \\ 10 & 38 & 33 \\ \text { Mean } & 26.9 & 18.5 \\ \text { SD } & 5.3 & 7.9\end{array}$

women without partners were less concerned about hair loss (29.56) than those with partners $(43.33)^{10}$.

The low incidence of symptoms $(24.9 \pm 19.2)$ is probably due to the fact that none of the participants was undergoing chemotherapy or radiotherapy at the time this study was carried out. According to other studies, patients who had undergone chemotherapy and mastectomy presented more symptoms of fatigue, nausea, vomit, and mild to moderate pain when compared to women with breast cancer who had been submitted only to chemotherapy ${ }^{10}$.

In another study, the authors concluded that resorting to surgery as a breast cancer treatment is a determining factor for the QL index. Following the application of questionnaire SF-36, the results pointed out that women who had undergone quadrantectomy and did not need reconstructive surgery had the best average scores in all domains and, therefore, had better QL, followed by the group that had undergone mastectomy and reconstruction. The group of mastectomized women who did not have reconstruction surgery had a very low QL, followed by the group of women who had undergone quadrantectomy but no reconstruction ${ }^{11}$.

The average of muscle strength on the healthy side of the sample in this study was $26.9 \mathrm{kgf}( \pm 5.3)$. On the affected side, it was $18.5 \mathrm{kgf}$ (7.9). In another study, the authors observed the frequency of these complications, as well as when the mastectomized women had been referred to physical therapy. The main complications were limited shoulder movement (61.9\%), pain (32.5\%), lymphedema (29.4\%), scar tissue adhesion (3.1\%), and alterations in sensitivity (2.5\%); $19.4 \%$ of the women had no complications. The medical referrals, in their majority, concerned the treatment of existing complications (76.9\%), only $23.1 \%$ of the women received referrals with the purpose of investing in prevention. The results of the study 
in question point out that the participants who had been referred for prevention did not present any alterations ${ }^{3}$.

In this sense, studies show that through physical therapy treatments conducted already in the pre-surgery period, the professionals aim at getting acquainted with previous alterations and verifying risk factors for the post-surgery stage. It is possible to begin this treatment both before and immediately after surgery, which contributes to the functional improvement of the AUL ${ }^{12,13}$.

In regards to physical therapy techniques, a study showed a significant increase $(p<0.0001)$ in the activation and strength of the medial deltoid and superior trapezius muscles of women submitted to modified radical mastectomy, with the use of proprioceptive neuromuscular facilitation (PNF). They were allocated in two groups: 1) recent mastectomy (up to two years after surgery); 2) less recent mastectomy (after two years of surgery), treated with the PNF technique, twice a week during four months. At the end of the treatment, the muscle strength of the AUL was assessed through electroneuromyography, and the AM was assessed with a goniometry. The improvements in strength and AM were more evident in the group with recent mastectomy, therefore the authors concluded that the earlier physical therapy interventions begin, the better the rehabilitation results and the reinsertion of these women in their daily activities ${ }^{14}$.

Finally, we highlight the limitation in relation to the population that integrates this study. Because the region in question is composed by small and medium-sized cities, we had difficulty to contact the women and have them travel from their cities to the location where the assessments were carried out. Thus, the initial selection of women who had undergone unilateral modified radical mastectomy at the hospital of reference in the region counted 48 individuals in the period that ranged from March 2011 to March 2012. Out of this number, 27 resided in nearby cities and were included in the study for this reason. However, 3 passed away and 24 were invited to participate in the study. Upon calculation of the sample, considering a standard error of 5\%, it was determined that the $\mathrm{n}$ of interviews to be conducted was 10 .

\section{CONCLUSION}

The results of this study show the impact of breast cancer on the QL of mastectomized women, especially on the social aspects of their lives. They also show the loss of muscle strength consequential of the surgical process that impacts the functionality of the AUL. Other studies highlight the importance of physical therapy in all phases of breast cancer treatments, as it is one of the main agents of prevention against post-mastectomy complications.

\section{REFERENCES}

1. Brasil. Estimativa 2014: Incidência de Câncer no Brasil; 2013 [Internet]. [Citado em 10 fev 2014]. Disponível em: <http://www2. inca.gov.br/wps/wcm/connect/O129baO041fbbcOlaa4fee936e134226/ Apresentacao+Estimativa+2014_final+corrigido+tireoide.pdf? MOD=AJPERES\&CACHEID=0129baO041fbbc01aa4fee936e134226>

2. Batiston AP, Santiago SM. Fisioterapia e complicações físicas funcionais após tratamento cirúrgico do câncer de mama [Internet]. Fisioter Pesqui. 2005;12(3):30-35. [Citado em 28 nov 2013]. Disponível em: <http://www. crefito3.com.br/revista/usp/05_09_12/pdf/31_complicacoes.pdf>

3. Fortner KD. Manual de ginecologia e obstetrícia do John Hopkins. 3a ed. Porto Alegre: Artmed; 2007.

4. Ferro ADM, Gontijo AD, Bottaro M, Viana J. O efeito do tratamento fisioterapêutico na biomecânica morfofuncional no pós-operatório do câncer de mama [Trabalho de Conclusão de Curso]. Rio de Janeiro: Universidade Gama Filho; 2003.

5. Segre M, Ferraz FC. O conceito de saúde. Rev Saúde Pública. 1997;31(5):538-42.

6. Aaronson NK, Ahmedzai S, Bergman B, Bullinger M, Cull A, Duez NJ, et al. The European organization for research and treatment of cancer QLQ-C3O: a quality-of-life instrument for use in international clinical trials in oncology. J Natl Cancer Inst. 1993;85(5):365-76.

7. O'Sullivan SB, Schmitz TJ. Fisioterapia: avaliação e tratamento. $2^{a}$ ed. Barueri: Manole; 2004

8. Anjos ACY, Paiva L, Sales CACCS, Scandiuzzi D. Qualidade de vida de mulheres tratadas de câncer de mama: funcionamento social. Rev Bras Cancerol. 2001:47(3):263-72.

9. Bezerra KB, Silva DSM, Chein MBC, Ferreira PR, Maranhão JKP, Ribeiro NL, et al. Qualidade de vida de mulheres tratadas de câncer de mama em uma cidade do nordeste do Brasil. Ciênc Saúde Coletiva. 2013;18(7):1933-41.

10. Albuquerque V, Leite J, Silva CB. Qualidade de vida em pacientes portadoras de neoplasia mamária submetidas a tratamento quimioterápico. Rev Bras Cancerol. 2010;56(2):227-36.

11. Simeão SFAP, Landro ICR, Conti MHS, Gatti MAN, Delgallo WD, Vitta AD. Qualidade de vida em grupos de mulheres acometidas de câncer de mama. Ciênc Saúde Coletiva. 2013;18(3):779-88.

12. Brasil. Controle do câncer de mama: documento de consenso; 2004 [Internet]. [Citado em 05 dez 2013]. Disponível em: <http://www.inca. gov.br/publicacoes/consensointegra.pdf>

13. Bergmann A, Nogueira EA, Oliveira ACG, Pedrosa E, Ribeiro MJP. Fisioterapia em mastologia oncológica: rotinas do Hospital do Câncer III. Rev Bras Cancerol. 2006;52(1):97-109.

14. Nogueira PVG, Guirro ECO, Guirro RRJ, Palauro VA. Efeitos da facilitação neuromuscular proprioceptiva na performance funcional de mulheres mastectomizadas. Fisioter Bras. 2005;6(1):28-35. 